\title{
Castellated Steel Beams-A Torsional Analysis
}

\author{
A. J. Mehetre, R. S. Talikoti
}

\begin{abstract}
Practice of castellated beams (CBs) or perforated beams for several structures speedily gaining petition. This is because of the increased depth in the segment, high strength to weight ratio, light in weight, easy to erect, economical, and stronger. The principal advantages of the castellated beam are an attractive provision, an increase in vertical bending stiffness, \& ease of service provision. The CBs is prepared from its virgin sections i.e. I beam by cutting it in a zigzag or any suitable cutting pattern and again rejoined it by welding therefore depth of the resulting section increases. The load-carrying capacity of the parent I section is increased with the same quantity of material and weight, due to an increase in depth of beams. Web post-buckling and lateral-torsional buckling failure occur when these beams are subjected to loading, this is the effect of an increase in depth of the castellated beams. There are five basic failure modes associated with castellated steel beams that need to be taken care of 1) Development of flexure mechanism. 2) Lateral-torsional buckling 3) Vierendeel mechanism 4) rupture of the welded joint in a web post 5) shear buckling of a web post. Therefore, in this research paper, an effort has been made to estimate the torsional moment capacity castellated beam for hexagonal or honeycomb opening with $30^{\circ}, 45^{\circ}, 60^{\circ}$ \& sinusoidal opening with different fillet radii. Keywords: Castellated beam, Hexagonal opening, Sinusoidal opening, Torsion.
\end{abstract}

\section{INTRODUCTION}

I-shaped hot rolled steel beams are extensively used as structural components because of their Flexural efficiency about the strong axis. However, in various applications beams are eccentrically loaded and as a result experience tensional loads in combination with bending. Like all solid sections, I-shaped steel beams are very inefficient interaction effects due to torsion, and resisting torsion acting in combination with bending can considerably reduce the capability of the solid beams, and hence CBs are the best solution under this situation. In most of the steel-framed structure, the beam is subjected only bending and not torsion but the situation does arise where torsion effect is significant the designer will also know the value of torsional effect and to consider the resistance of member under the combined bending and torsion Steel beams with an opening in the web part are called castellated steel beams (CSBs). I-shaped section is a very efficient form for carrying both bending and shears loads in the plane of the web. On the other hand, the cross-section has a reduced capacity in the transverse direction and is also inefficient in carrying torsion, for which hollow structural sections are often preferred.

Revised Manuscript Received on May 15, 2020.

* Correspondence Author

A. J. Mehetre*, Research Scholar, Late G. N. Sapkal COE, Nashik, SPPU, Maharashtra, India. Email: mehetreaj@rediffmail.com

R. S. Talikoti, Associate Professor, R. H. Sapat COE, management studies \& research, Nashik, SPPU, Maharashtra, India. Email: rstalikoti@gmail.com

(C) The Authors. Published by Blue Eyes Intelligence Engineering and Sciences Publication (BEIESP). This is an open access article under the CC BY-NC-ND license (http://creativecommons.org/licenses/by-nc-nd/4.0/)
CBs offer a designer all types of prospects for "cutting to size". For example, in simple straight castellated beams, by changing the cutting pattern the depth can be determined therefore in this technique, the strength of the beam for the occurring loads should be precisely matched. That's what you call optimum construction! In addition to this, a tapered shaped castellated beam easily built, at a slight angle by setting the cutting design not exactly parallel to the length of the castellated beam. After cutting, among two halves, one is reversed and the two halves are then welded together lengthwise. At one end both low sides come together, at the other end both high sides. CBs are such structural supporters, which are prepared by flame cutting a hot rolled steel beam lengthwise its centerline and then rejoining the two halves by welding, and hence the overall depth of the beam is increased by $50 \%$ for better structural presentation against bending, flexure, and shear. Commonly, for CSBs hexagonal, rectangular, oval, elongated circular and circular shaped opening are provided, which are distributed at consistent intervals in the web of the CBs. These are finished from I-section (hot-rolled) which is being cut lengthwise with definite configuration and then both halves are moved and re-welded such that results increases in depth. The castellated steel beam achieved is 50\% deeper than virgin I-Section i.e. 1.5 times the depth than the original section. Fig. 1 shows CBs with the hexagonal shaped opening, a castellated beam with the sinusoidal opening as shown in Fig. 2.

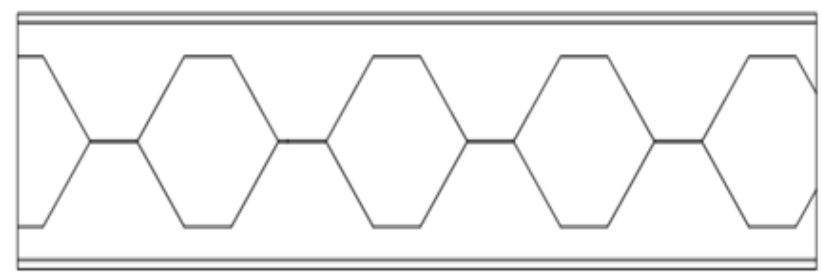

Fig.1. Hexagonal opening CBs.

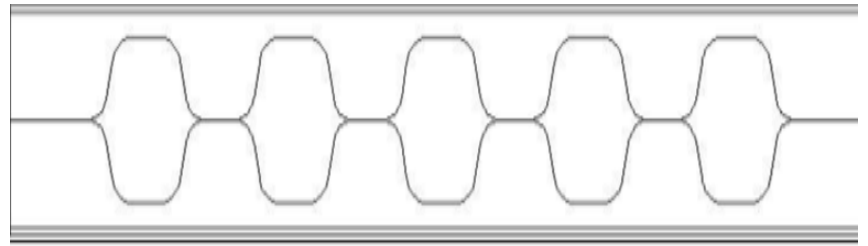

Fig.2. Sinusoidal opening CBs.

\section{LITERATURE SURVEY}

1. L.M. Gupta ${ }^{\text {etal }}$ carried out experimental investigation \& ANSYS analysis on a hexagonal opening castellated beam under constant loading \& support condition.

\section{Published By:}

Blue Eyes Intelligence Engineering

\& Sciences Publication

(C) Copyright: All rights reserved. 


\section{Castellated Steel Beams-A Torsional Analysis}

They were also observed deflection pattern at a mid-span of the castellated beam by using different depth of a section \& changing the location of hexagons along the length of the beam.

2. B. Anupriya \& Dr. K. Jagadeesan investigated shear strength analysis on the castellated beam by using ANSYS software. He observed that because of stress concentration at the opening corner more deflection occurred \& to reduce this deflection they provided vertical \& diagonal stiffener.

3. Delphine Sonck \& Jan Belis investigated the effect of residual stresses which is occurred due to the fabrication process, which makes design unsafe. They were analyzed results obtained from the numerical model of castellated beam residual stresses \& validate it with experimental results.

4. S. Durif \& A. Bouchair gives the analytical approach based on existing methods for multiple opening and also based on plate buckling theory. They also proposed a formula for calculation of the critical stress coefficient. He compared this study with finite analysis for sinusoidal opening.

5. Sahar Elaiwai ${ }^{\text {etal }}$ investigated the effect of web opening on the transverse deflection of the castellated beam by using analytical method \& measured deflection of the castellated beam for varying its length \& flange width subjected to uniform loading which is based on the principle of minimum potential energy.

Research Gap: Most of the research work is undergone with deflection analysis of castellated beam with a different geometrical opening but very less work with torsional analysis of castellated. So these papers mainly focus on the torsional analysis of castellated beam with hexagonal opening \& sinusoidal opening.

\section{OBJECTIVE \& INVESTIGATION}

1. To observe the torsional behaviour of the CBs with hexagonal and sinusoidal web opening.

2. To investigate the effect of a number of key parameters on the behaviour of I-shaped castellated steel beams under torsion

3. To compare analytical and experimental investigation.

4. To study different failure mode in a castellated beam

4. To find the most suitable section for more torsional moment carrying capacity as compare to the solid section.

\section{GUIDELINES FOR DESIGN}

\section{A. General Information}

In this chapter the methodology and materials used are discussed in detail. To carry out the castellation process and the testing purpose parent steel section ISMB 150 was used. The table -I shows the properties of the ISMB 150 solid section. Table- II shows the specimen details.

Table- I: ISMB 150 sectional properties details.

\begin{tabular}{|l|l|}
\hline Beam type & ISMB 150 \\
\hline A, Area of the section in $\mathrm{mm}^{2}$ & $39.72 \times 10^{2}$ \\
\hline D, Depth of the section in $\mathrm{mm}$ & 150 \\
\hline
\end{tabular}




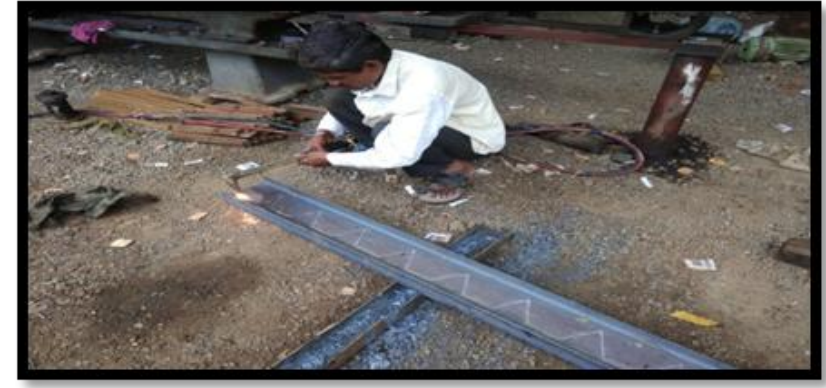

Fig.3. Marking and cutting the parent beam.

- Separation and Relocation of section -

After cutting to achieve the required size \& the shape of the opening, separated two halves of the section are arranged at their apex points as shown in Fig 4.

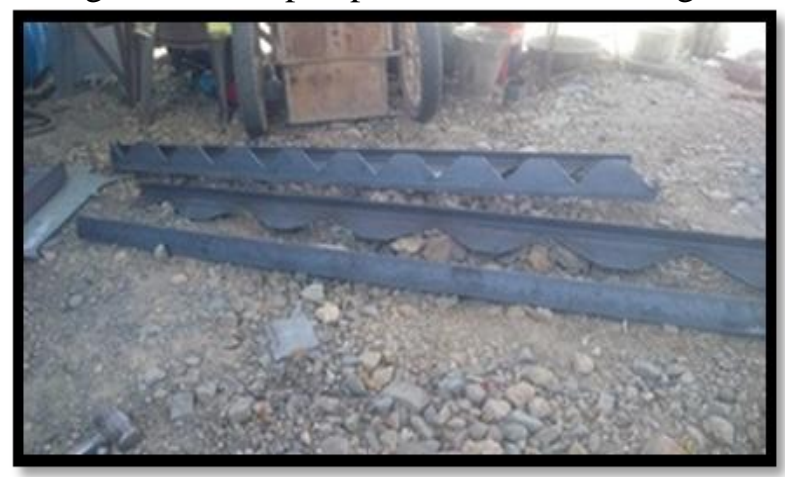

Fig.4.Separation and Rearrangement of two halves of section.

\section{- Rejoining by using welding -}

Finally, welding of the high points of web post back together is done with the help of a gas cutter or an automated submerged arc welding process; to build the required depth of castellated beams as shown in Fig 5.

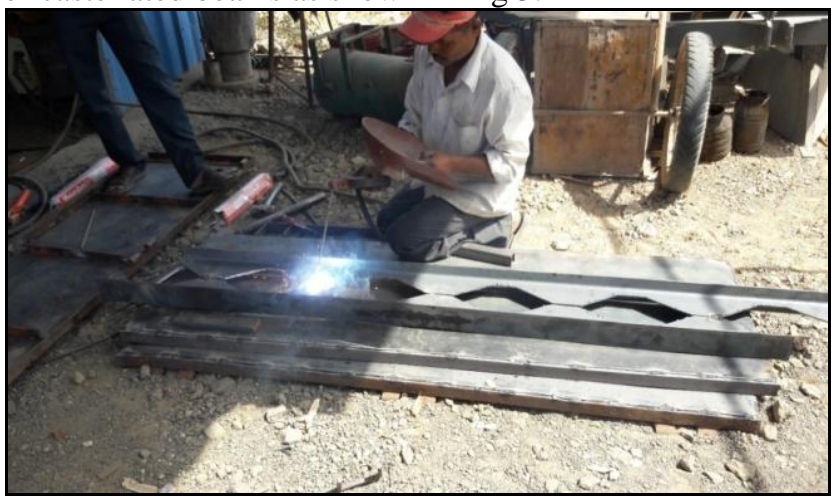

Fig. 5. Welding of Castellated Beam for hexagonal

opening.

\section{TESTING PROCESS}

A. Testing Apparatus (Torsion Setup) of Castellated beams on UTM

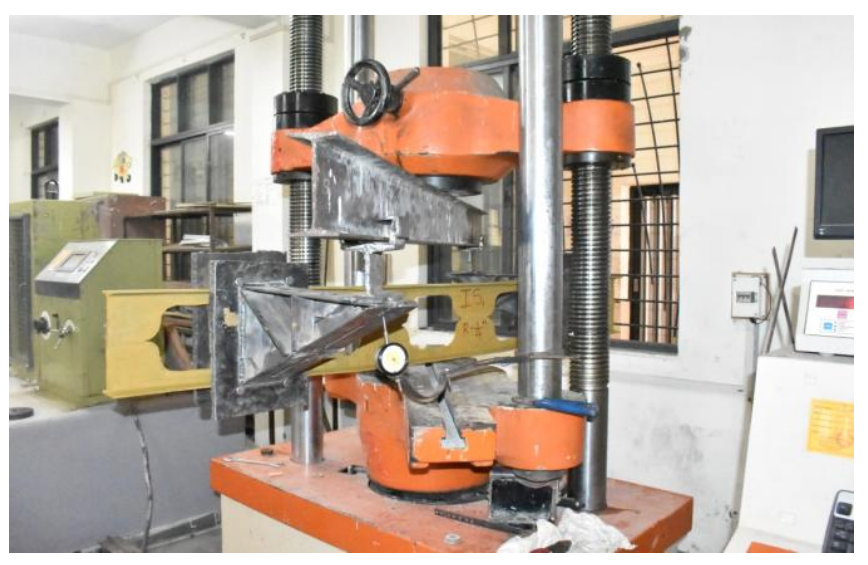

Fig. 6: Torsion Assembly of Castellated beams for Torsion Test.

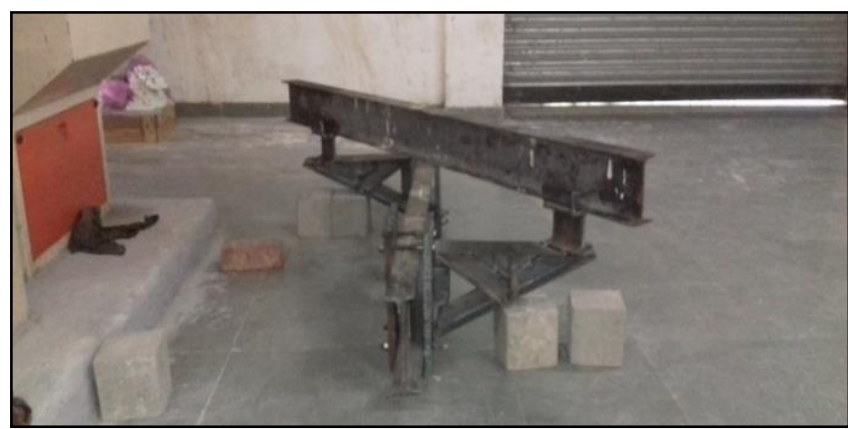

Fig. 7: Assembly of Twist Triangles.

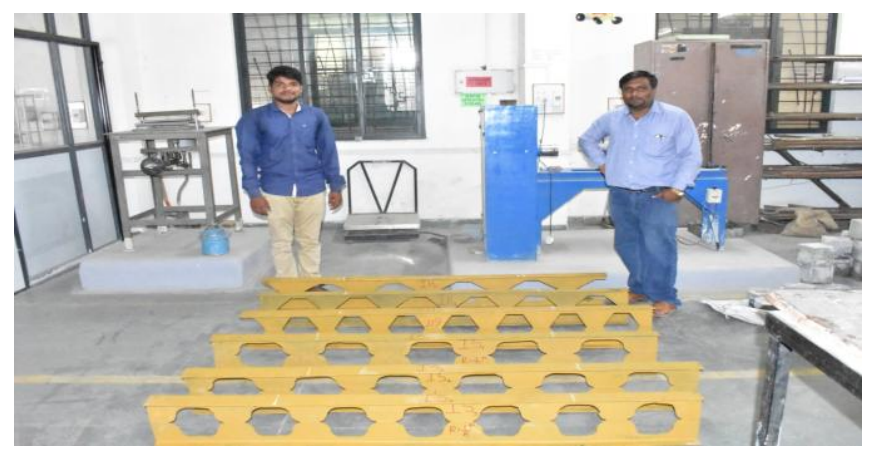

Fig. 8: Specimens of the castellated beam.

Fig.6 showed the testing is carried out by using the torsion test set up in UTM. The twist triangle assembly is shown in Fig.7. The entire fabricated samples are shown in Fig.8.Table- III, and Table-IV show experimental and analytical outcomes. The behavior of all the castellated beams i.e. torsional moment verses angle of twist as presented graphically. Comparisons of all experimental and analytical results presented in graphs 7 and 8.

\section{A. Sample Observation table}

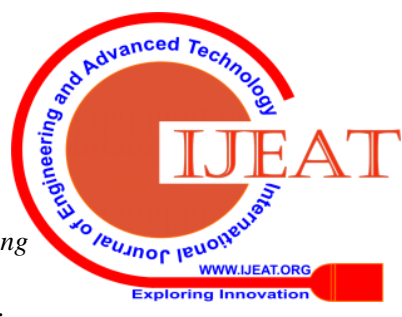




\section{Castellated Steel Beams-A Torsional Analysis}

Table No. III- Experimental result

\begin{tabular}{|c|c|c|c|c|c|}
\hline Sr No. & Notation & $\begin{array}{l}\text { Load } \\
(\mathrm{KN})\end{array}$ & $\begin{array}{c}\text { Deflection } \\
(\mathrm{mm})\end{array}$ & $\begin{array}{c}\text { Torsional } \\
\text { Moment } \\
(\mathrm{KN} . \mathrm{M})\end{array}$ & $\begin{array}{c}\text { Angle of twist } \\
\text { (Radian) }\end{array}$ \\
\hline 1 & IP & 24.5 & 93 & 5.5125 & 0.14719765 \\
\hline 2 & IH1 & 27.8 & 75 & 6.255 & 0.167448079 \\
\hline 3 & IH2 & 24.3 & 90 & 5.4675 & 0.201357921 \\
\hline 4 & IH3 & 32.8 & 50 & 7.38 & 0.111341014 \\
\hline 5 & IS1 & 25 & 118 & 5.625 & 0.265 \\
\hline 6 & IS2 & 25.9 & 76.4 & 5.8275 & 0.1706 \\
\hline 7 & IS3 & 26.9 & 96 & 5.06 & 0.214985573 \\
\hline
\end{tabular}

Torsional moment Vs Angle of twist

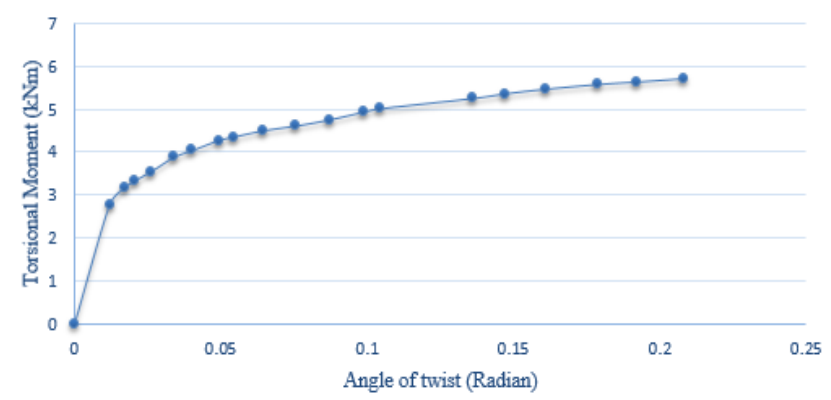

Graph 1: Torsional moment Carrying Capacity of IP V/s Angle of twist.

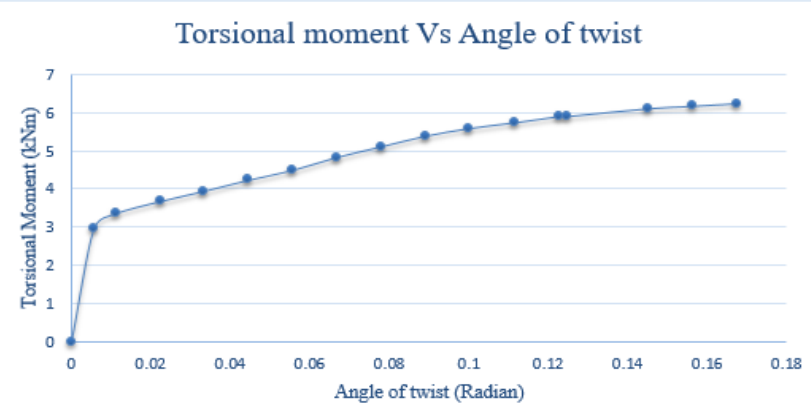

Graph 2: Torsional moment Carrying Capacity of $\mathbf{I H}_{1} \mathrm{~V} / \mathrm{s}$ Angle of twist.

Torsional moment Vs Angle of twist

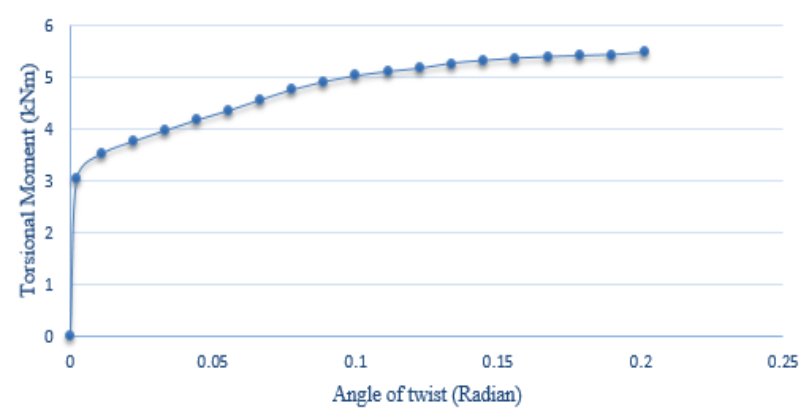

Graph 3: Torsional moment Carrying Capacity of $\mathbf{I H}_{2} \mathrm{~V} / \mathrm{s}$ Angle of twist.

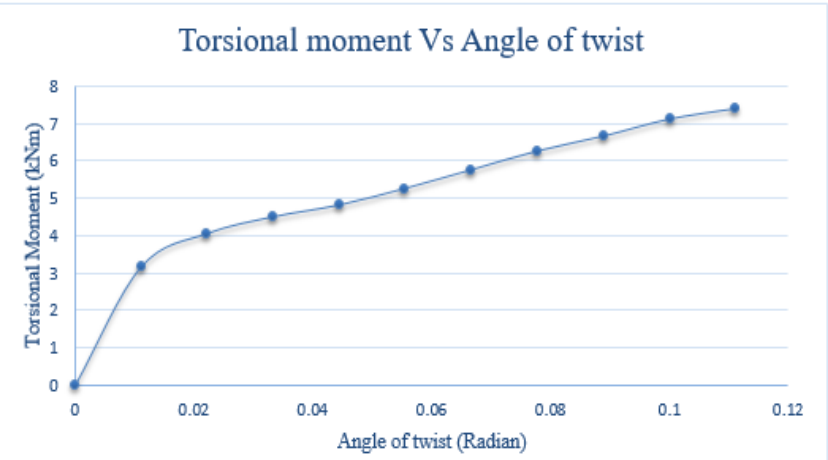

Graph 4: Torsional moment Carrying Capacity of $\mathrm{IH}_{3} \mathrm{~V} / \mathrm{s}$ Angle of twist.

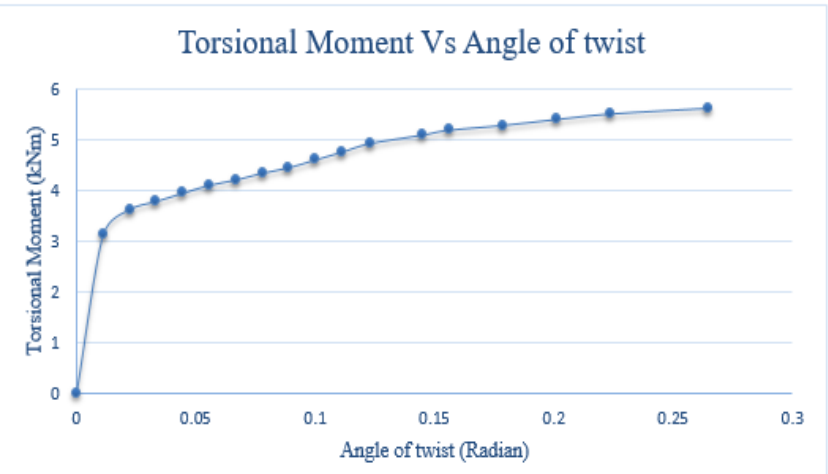

Graph 5: Torsional moment Carrying Capacity V/s Angle of twist for $\mathrm{IS}_{1}$ with fillet radius $1 / 4^{\text {th }}$.

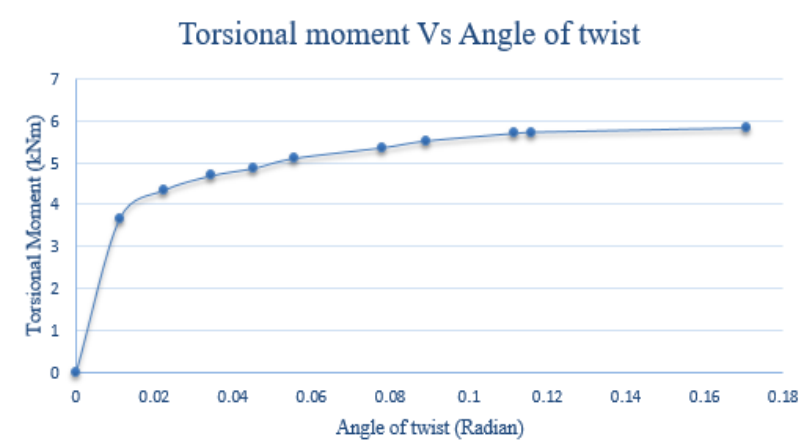

Graph 6: Torsional moment Carrying Capacity V/s angle of twist for $\mathrm{IS}_{2}$ with filleted radius $1 / \mathbf{6}^{\text {th }}$

Torsional moment Vs Angle of twist

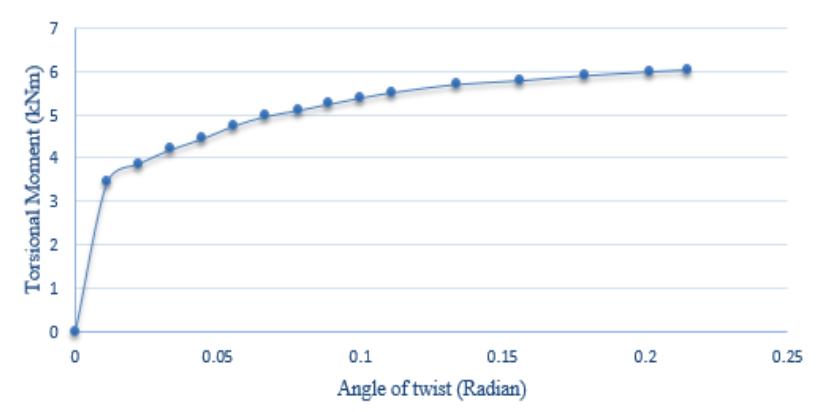

Graph 7: Torsional moment Carrying Capacity V/s angle of twist for $\mathrm{IS}_{3}$ with filleted radius $1 / 8^{\text {th }}$.

Published By:

Blue Eyes Intelligence Engineering

DOI: 10.35940/ijeat.E9606.069520

\& Sciences Publication

Journal Website: www.ijeat.org

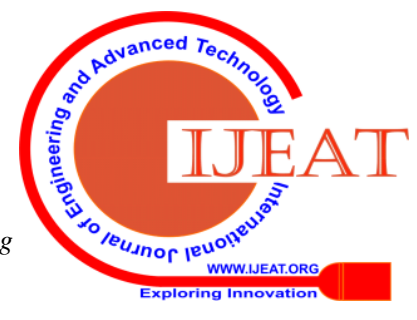




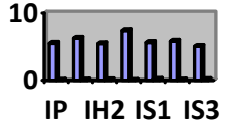

\begin{tabular}{c}
\hline Torsional \\
Moment \\
$\begin{array}{c}\text { Angle of } \\
\text { twist }\end{array}$ \\
\hline
\end{tabular}

Graph 8: experimental results comparisons of various sections.

Table No. IV Result obtained by ANSYS Software

\begin{tabular}{|c|c|c|c|c|c|}
\hline Sr.No. & Notation & $\begin{array}{l}\text { Load } \\
(\mathrm{KN})\end{array}$ & $\begin{array}{c}\text { Deflection } \\
(\mathrm{mm})\end{array}$ & $\begin{array}{c}\text { Torsional } \\
\text { Moment } \\
(\mathrm{KN} . \mathrm{M})\end{array}$ & $\begin{array}{c}\text { Angle of twist } \\
\text { (Radian) }\end{array}$ \\
\hline 1 & IP & 24.5 & 91 & 5.5125 & 0.14719765 \\
\hline 2 & IH1 & 27.8 & 92 & 6.255 & 0.15394062 \\
\hline 3 & IH2 & 24.3 & 69 & 5.4675 & 0.194558449 \\
\hline 4 & IH3 & 32.8 & 54 & 7.38 & 0.120289882 \\
\hline 5 & IS1 & 25 & 116 & 5.625 & 0.261 \\
\hline 6 & IS2 & 25.9 & 78 & 5.8275 & 0.1746 \\
\hline 7 & IS3 & 26.9 & 91 & 5.06 & 0.203626494 \\
\hline
\end{tabular}

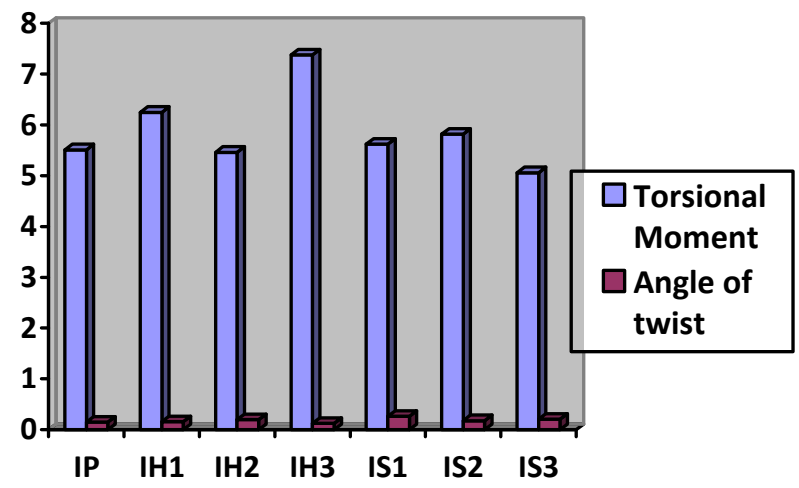

\section{Graph 9: Comparisons of Analytical results (ANSYS )}

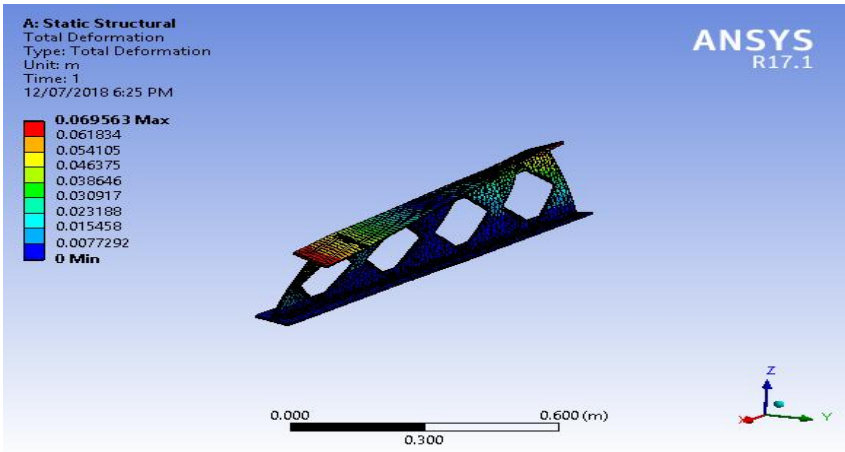

Fig.9: Total angle of twist of $\mathrm{IH}_{1}$.

1. Experimental results show that the castellated section increases the torsional moment carrying capacity as compared to the solid section.

2. The hexagonal section with the angle of opening $60^{\circ}$ shows a $29 \%$ larger torsional capacity as compared to parent

3. Sinusoidal section with the angle of opening $30^{0}$ shows 9.5 \% larger torsional capacity as compared to parent sections. 4. As per as angle of twist is concern $\mathrm{IH}_{2}$ and $\mathrm{IS}_{1}$ showed the maximum angle of twist.

5. All the experiment results are validated by the ANSYS software.

\section{REFERENCES}

1. Parametric study of castellated beam by P.D. Pachore, L. M. Gupta, N. U. Deshpande \& Komal Bedi, Advanced material research, Vol-163-167,2011, P.P- 842-845.

Strength study of castellated beam by B. Anupriya \& Dr. K. Jagadeesan, International journal of engineering research \& technology, Vol-2,

. Lateral torsional buckling resistance of castellated beam by Delphine

Analytical model to predict the resistance of cellular beam with sinusoida research, Vol- 1212, 2016, PP- 80-96.

5. Bending analysis of castellated beam by Sahar Elaiwi, Boksun Kim \& Long yuan Li, Athens journals of technology \& engineering, Vol-6, Issue-1, PP-1-16, March 2019.

6. ANSYS Software version 17.1(2017)

\section{AUTHORS PROFILE}

First Author

Mr. Mehetre Amol J.

Research Scholar, Department of Civil Engineering, LGNSCOE, Nashik, (MS) India.

mehetreaj@rediffmail.com

\section{Second Autho}

Dr. Talikoti Rajashekhar S.

Research Guide, Civil Engineering Department, R. H. Sapat College of Engineering, management studies, Nashik, (MS) India. rstalikoti@gmail.com 